\title{
Az év, amikor minden megváltozott (?)
}

A magyarság nemzeti sorskérdések iránt fogékony tagjai érthető szorongással tekinthettek a 2020. év elébe. Az éjfélt ütő óra, az újévi jókívánságok ideje most nem csak egy másik esztendő beköszöntét jelezte. Elérkezett a trianoni békediktátum századik évfordulója. 1920-ban népünk életében döntő változások következtek be, amelyek máig súlyos teherként nehezednek ránk. A kormány direktívái egyértelműek voltak: Trianon emléke magyar ügy. Nem ülünk fel provokációknak, nem panaszkodunk és vádaskodunk senkinek, nem terheljük kapcsolatainkat a környezö népekkel. Már csak utódaink és az elszakított nemzetrészek érdekében is a közös eredményeket hangsúlyozzuk, és a jövőbe tekintünk.

Eközben az év elején már lehetett hallani egy, a kínai Vuhan városában terjedő betegségről, amely különösen agresszív tüdőgyulladásos tüneteket produkál, vakcina és ismert gyógyszer pedig nincs ellene. Európa társadalmaiban két hónapon át szerény érdeklődésre tartott számot e jelenség, mígnem márciusra egyértelművé vált, hogy a közkeletủen koronavírusnak nevezett kórokozó kitört Kelet-Ázsiából, és immár nyugaton is terjedőben van. A WHO március 11-én hirdette ki a világjárványt, amelynek keretében olyan jelentős országok, mint Irán, Olaszország, Spanyolország, az Amerikai Egyesült Államok és az Egyesült Királyság viharos gyorsasággal szembesültek katasztrofális közegészségügyi állapotokkal.

Megismerkedett a világ egy új típusú gazdasági válsággal is. Olyan depresszióval, amelynek nincsenek megszokott, a gazdaság szerkezeti problémáiból és/vagy müködési mechanizmusainak hibáiból fakadó okai, hanem egyszerüen a tevékenységek mesterséges elfojtása, az országok és emberek bezárkózása, passzívabbá válása idézett elő. És persze jöttek a személyek mozgását korlátozó, intézmények müködését nemritkán katonai jellegű vészhelyzeti tervek szerint szabályozó vagy átformáló intézkedések. Csupa olyan tapasztalat, amelyet az ilyesmitől régen elszokott európaiak a háborús helyzetekkel azonosítanak. Miközben egyetlen puskalövés sem történik, a veszteségek mindenki számára nyilvánvalók, ha másért nem, hát az elhunytak naponta bővülő száma miatt.

Jóllehet, a szakértelmiség továbbra is kötelességének érzi „elemzésekkel” ellátni a széles közvéleményt, megfelelő tapasztalatok és információk hiányában valójában egyelöre senki sem tudja, hogy a veszélyhelyzet gazdasági és társadalmi hatásai meddig terjednek majd. A politikai elemzők jobbára azt találgatják, hogy milyen változások történhetnek a világ hatalmi egyensúlyában, a nagyhatalmak közötti gazdasági viszonyok tekintetében. Mások a rendkívüli intézkedések tartós hatásairól spekulálnak, a nemzetállami keretek erősödését, az európai együttmüködésen belüli ellentétek fokozódását, végső soron a keretek radikális megváltozását vizionálva. Mellesleg csupa olyan kérdés, amely az első világháború végnapjaiban is felmerült. 
Mostanra egyértelmű: nemcsak Magyarország, de egész Európa számára emlékezetes lesz a 2020-as esztendő. Ám ennek a helyzetnek már nincsenek haszonélvezői, az egymásra utaltságunk miatt végső soron a károk is közösek, a veszteség érzése pedig, amely az év elején még magyar ügynek látszott, mostanra összeurópai jelenséggé vált. Ez, valamint az elmúlt évszázad tapasztalatai azonban a továbblépés együttmúködésen és szolidaritáson alapuló útját is kijelölik. A talpra álláshoz szükséges lelkierő és a jövőbe tekintés ma éppoly fontos, mint száz évvel ezelőtt - de már nem csak Magyarországnak. 